\title{
Functional Background and Business Strategy: The Impact of Executive-Strategy Fit on Performance
}

\author{
John A. Parnell \\ Middle Tennessee State University \\ Murfreesboro, Tennessee
}

For the past several decades, business experts have sought to identify functional backgrounds and personal characteristics most suitable for successful business leadership (Govindarajan 1989; Gupta and Govindarajan 1984; Hambrick and Mason 1984; Miller, Kets de Vries and Toulouse 1982; Norburn 1989; and Thomas, Litschert, and Ramaswamy 1991). Some have emphasized the strengths of a given functional background such as engineering or marketing. Others have focused on the likelihood that managers with given functional backgrounds will rise to the level of top executive (Dommermuth 1966 and Kurtz, Boone, and Fleenor 1989). Still others have emphasized tasks and activities associated with the top executive or top management team and how various responsibilities necessitate specific top management skills (Hise and McDaniel 1988; Litchfield 1990; and Murray 1989).

During this same time, strategists sought to discover the "perfect strategy," or at least identify the characteristics of successful business strategies in isolation of the managers responsible for their formulation and implementation. Typologies proposed by Porter (1980, 1985) and Miles and Snow (1978) sparked several insightful debates on the strategy-performance relationship. Although each generic strategy identified in the typologies suggests leadership competencies essential for its effective implementation, one key question remains: Does the success of a given strategy hinge on the functional background of the top executive? This article seeks to answer this question by examining an executive-strategy contingency among retail department stores. In doing so, reviews of past functional background and strategy research are provided, followed by the development of propositions, a discussion of testing procedures, and results of the study. A discussion and prospects for future research are identified.

\section{The Top Executive and Functional Background}

Most top executives possess a distinct functional orientation (Hambrick and Mason, 1984). Dommermuth (1966) provided the earliest comprehensive analysis of top executive functional backgrounds. During the period from 1945 to 1964, he found that general management and production produced the greatest number of top executives in the sample $(22 \%)$, while marketing (18\%) and finance $(16 \%)$ backgrounds were also common. In his conclusions, Dommermuth identified one key trend: Managers who successfully rose through the ranks of one specialization have the brightest prospects for becoming top executives.

The two decades that followed vindicated Dommermuth's assessment. The 1970s witnessed the culmination of the age of mass marketing, bringing about a demand for executives with marketing expertise. The tough economic times of the late seventies and 
early eighties spawned a demand for executives with strong financial backgrounds. However, the demand for top executives in the 1990s appears to have reversed this trend. Recent surveys suggest that organizations are actively seeking visionaries with a generalist perspective and expertise in almost all functional areas (Kichen and Hardy 1992; Kurtz, Boone, and Fleenor 1989; and Litchfield 1990). Nonetheless, many writers continue to argue the merits of top executives with expertise in one particular discipline or another. Five broad functional areas are discussed below; (1) research and engineering, (2) marketing and sales, (3) accounting and finance, (4) manufacturing and production, and (5) general management.

Braham (1991) presented a strong case for promoting engineers to top executive positions. Indeed, activity during the past 15 years demonstrates that others agree. Specifically, the number of top executives with engineering backgrounds has risen steadily from $7 \%$ of the largest 1000 U.S. companies in 1977 to $18 \%$ in 1987. Further, of the 243 top executives who participated in Kurtz et al.'s (1989) extensive study, 24\% reported engineering backgrounds. Braham argued that the increased global competition, often spurred by advanced Japanese engineering and design, has increased the need for engineers at the top. Further, engineers by nature tend to be innovative, research-oriented, and open-minded, attributes essential to effective organizational leadership (Braham 1991).

According to Boone and Milewicz (1989), the characteristics of the successful sales professionals-stable, self-sufficient, self-confident, goal-directed, decisive, speedy, accurateare most closely associated with those of successful top executives. Futrell (1988) alsó noted that professional selling offers the fastest opportunity for advancement. Indeed, more top executives over the past several decades have come from marketing backgrounds than any other (Kurtz, Dodge, and Klompmaker 1988). However, there exists no conclusive evidence to suggest a continuance of this trend (Boone and Milewicz 1989).

Flannigan's (1986) survey of the nation's largest 800 corporations found the highest percentage of top executives (34\%) to possess financial, banking, or accounting backgrounds. Many experts have attributed the rise in the number of financial specialists as top executives to the increased emphasis on developing and maintaining a leaner, more competitive organization (Flannigan 1986; Litchfield 1990). Indeed, banking and financial experts rose steadily in the 1980 s (Boone and Kurtz 1988) but will likely decline as the environment changes in the 1990s.

The case for manufacturing and production specialists as top executives is similar to the one made for those with research and engineering backgrounds. However, proponents have argued that production and manufacturing backgrounds have better equipped managers to formulate and implement the quality-based strategies of the 1990s (Eisman 1992; Hendricks and Triplett 1990). In addition, the successful implementation of total quality management (TQM) techniques as part of a global strategy has been linked to top management teams with a production slant (Sashkin and Kiser 1992).

The final functional area-general management-includes a wider variety of activities and experiences than any of the other four. The executive with a general management background likely possesses limited experience in some or all of the other more specific func- 
tional areas (Kotter 1982). However, the general manager retains expertise in no specific field. As a generalist, he or she may experience a greater understanding of the organization as a whole, but without a depth of knowledge in a key functional area.

\section{Strategy and Performance}

Researchers have classified business strategies into typologies to more effectively study relationships between strategy and performance (Herbert and Deresky 1987; Hill 1988; Lawless and Finch 1989; Namiki 1989; Parnell and Wright 1992). Strategic typologies represent broad categorizations of businesses' strategic behaviors into a few types. The two most widely researched typologies were pioneered by Porter (1980) and Miles and Snow (1978).

According to Porter's $(1980,1985)$ typology, a business can maximize performance either by striving to be the lowest cost producer in an industry or by differentiating its line of products or services from other businesses. A low cost strategy necessitates the business' ability to design, produce, and market a comparable product more efficiently than its competitors. The differentiation strategy emphasizes the ability of the business to provide unique and superior value to the buyer in terms of product quality, special features, or after-sale service. Differentiation leads to market success not based on a competitive price, but on the demands of a sophisticated consumer who wants a differentiated product and is willing to pay a higher price. According to Porter, either approach may be employed in conjunction with a focus strategy-concentrating ones efforts on a given segment of the market.

Porter suggested that businesses should seek to implement either a low cost or a differentiation strategy. Those that do not, instead attempting to accomplish both simultaneously, become "stuck in the middle." As such, these businesses do not tend to achieve superior performance (Dess and Davis 1984; Hambrick 1983). However, mounting empirical evidence has presented a strong case that, for many organizations, combination strategies are not only viable, but may be optimal (Buzzell and Gale 1987; Hill 1988; Jones and Butler 1988; Miller and Friesen 1986; Murray 1988; Parnell and Wright 1992; White 1986; Wright 1987; and Wright and Parsinia 1988). Indeed, businesses employing combination strategies may actually outperform those principally adopting either the cost leadership or differentiation strategies (Cappel 1990).

The Miles and Snow (1978) framework considers four strategic types: prospectors, defenders, analyzers, and reactors. Prospectors perceive a dynamic, uncertain environment and maintain flexibility to combat environmental change. Defenders perceive the environment to be stable and certain, and thus seek stability and control in their operations to achieve maximum efficiency. Analyzers stress stability and flexibility, and attempt to capitalize on the best of both of the preceding strategic types. Reactors lack consistency in strategic choice and perform poorly. Numerous studies conclude that superior performance can typically be found in prospectors, analyzers, and defenders, while reactors tend to perform poorly (Miles and Cameron 1982; Parnell and Wright 1992; and Snow and Hrebiniak 1980). 
Wright, Kroll, Pringle, and Johnson (1990) proposed a fifth organization type. The "balancer" is a combination of three types of organizations identified by Miles and Snow: the prospector, the analyzer, and the defender. The "balancer" is not a compromise strategy whereas the analyzer has been viewed as such (Hambrick 1983; and Wright et al. 1990). The balancer represents an ideal that reflects the ability of a business to synergistically incorporate elements of all viable generic strategies. Thus, the "balancer" and the "analyzer" should not be confused.

\section{The Fit: Strategy and Top Executive Background}

The linkage between executive characteristics and organizational performance is not without previous discourse (Norburn and Birley 1988; and Virnay and Tushman 1986). Over a decade ago, Miller, Kets de Vries and Toulouse (1982) argued for a relationship between top executive personality and strategic behavior. More specifically, different strategies require various distinct managerial tasks and behaviors for effective implementation (Andrews 1971), and general managers differ in their abilities to perform the necessary tasks, in part due to differing functional backgrounds (Kotter 1982). Hence, the business units most likely to achieve superior performance are those that match the requirements of their strategies to the functional expertise of their general managers (Govindarajan 1989; and Gupta and Govindarajan 1984).

Two notable studies have considered a fit between top executive and business strategy. Gupta and Govindarajan (1984) found that a marketing background was most appropriate for growth-oriented strategies, but inhibited performance of business units adopting a harvest-oriented strategy. Govindarajan (1989) found that research and development and marketing backgrounds contributed to superior performance in the case of differentiation SBUs, whereas manufacturing, finance, and accounting backgrounds were most appropriate for cost leadership business units.

This paper builds on the existing foundation and empirical work pioneered by Gupta and Govindarajan (1984) and Govindarajan (1989), but utilizes the Miles and Snow (1978) typology instead of Porter's (1980) approach. To craft a better understanding of the relationship, this study considers four viable strategies (i.e., prospectors, defenders, analyzers, and balancers) instead of two polar strategies (i.e., low cost and differentiation), as addressed in the other studies. The following propositions are tested in this study:

1. Prospector businesses with top executives from research and engineering or general management backgrounds tend to outperform prospector businesses with top executives from all other backgrounds.

Prospectors tend to possess a loose structure, a low division of labor, and low formalization and centralization. The strength of the prospector is the identification and exploitation of new product and market opportunities. Miles and Snow (1986) later referred to prospectors as the industry "designers." Leontiades (1982) noted that such a strategy 
necessitates product management and research skills. Hence, top executives from research and engineering or generalist backgrounds appear to possess the skills necessary to most effectively formulate and implement the prospector strategy.

2. Analyzer businesses with top executives from marketing backgrounds tend to outperform analyzer businesses with top executives from all other backgrounds.

Analyzers exert tight control over existing operations with loose control for new undertakings. The strength of the analyzer is the ability to imitate or respond to prospectors while maintaining efficiency in operations. Since analyzers are the "marketers" of an industry (Miles and Snow 1986), top executives with marketing backgrounds should be best equipped to oversee an analyzer organization.

3. Defender businesses with top executives from accounting, finance, manufacturing, production, or general management backgrounds tend to outperform defender businesses with top executives from all other backgrounds.

Defenders incorporate an extensive division of labor, high formalization, and high centralization. Defenders are the "producers" in an industry (Miles and Snow 1986). The strength of the defender is its high degree of concentration on only one segment of the market and its ability to serve this segment efficiently. Since production efficiency lies at the core of this strategy, top executives from backgrounds such as accounting, finance, manufacturing, production, or general management should possess optimal skills for formulation and implementation of the defender strategy.

4. Balancer businesses with top executives from general management backgrounds tend to outperform balancer businesses with top executives from all other backgrounds.

The balancer organization is uniquely positioned to utilize the advantages of the prospector, analyzer, and defender strategies. Specialist top executives that implement this strategy tend to operate at a disadvantage since their expertise may be severely limited in one of the strategic spheres. On the contrary, top executives from a generalist perspective may possess the "balance" of perspectives necessary to generate the synergy required for successful implementation of the balancer strategy.

5. Businesses with top executives possessing high amounts of experience in an organization, experience as top executive, and experience in the industry, tend to outperform other businesses, regardless of strategy or top executive background.

Govindarajan (1989) found a positive correlation between managerial experience and business unit performance. As such, this proposition tests the notion that strategy and functional background may not provide a thorough explanation of business performance. 
Instead, the level of experience for the top executive should tend to result in superior performance aside from strategic or expertise considerations.

\section{Methodology}

Industry categories based on four-digit SIC classifications have been a generally accepted unit of analysis in strategy research (Thomas and Venkatraman 1988). The industry examined in this study, SIC-5311, is comprised of department stores. Top executives in the industry were asked to provide information concerning their years of experience in the industry, with the present organization, and as top executive. In addition, top executives were asked to classify their functional background as research/engineering, marketing/sales, manufacturing/production, finance/accounting, law, or general management.

Fifteen items were generated to measure generic strategy (see Table 1), including items typically associated with the five hypothesized strategic types. Business performance was measured by return on assets (ROA) and growth in revenues from 1987 and 1991. A Likert-oriented instrument consisting of the top executive, strategy and performance items was sent to the top executives of the 299 largest businesses in the industry (Ward's Business Directory, 1992). This sample constitutes all reporting businesses with sales in excess of $\$ 1,000,000$ in 1991 . Usable responses were received from 129 businesses- a 43 percent response rate. The application of a factor analysis and calculation of Cronbach's (1951) alpha provided support for the integrity of the scale (Peter, 1979). Results of these preliminary tests appear in Table 1 .

\section{Table 1: Strategy Items and their Factor Loadings}

\begin{tabular}{lrc}
\hline \multicolumn{1}{c}{ Item } & Variable & Loading \\
\hline Ability to be new product leader & NEWPROD & .85 \\
Stability of product mix & STABPR & .64 \\
Emphasis on new product development & NPDEVEL & .83 \\
Emphasis on securing short term profit & STPROF & -.48 \\
Emphasis on securing market share & MSHARE & .91 \\
Range of product line & RANGE & .88 \\
Emphasis on being highly innovative & INNOVAT & .88 \\
Attitude toward growth & ATTGROW & .88 \\
Approach toward customer base & APPCUST & .84 \\
Stability of customer base & STABCUS & .91 \\
Stability of growth & STAGROW & .89 \\
Employee specialization & SPECIAL & -.52 \\
Flexibility of operations & FLEXIBL & .74 \\
Overall marketing strength & MKTGSTR & .82 \\
Emphasis on having lowest costs possible & LOWCOST & -.79
\end{tabular}


Scores for mean ROA ("ROA") and growth in revenue ("GRO") were calculated for each business. The correlation between the two dimensions of performance was 0.44 , significant at the .05 level. These two scores were then equally weighted relative to other businesses in the sample to form a composite measure of performance-a measure that incorporates two key facets of performance. The composite measure (COM) was scaled such that performance at the sample median for each generic strategy would yield a score of zero, with a standard deviation of 100 . Hence, a positive COM means that composite performance exceeded the median for businesses adopting the same strategy, while a negative COM means that composite performance was below the median.

Ward's clustering method (see Barney and Hoskisson 1991) was applied to the fifteen strategic variables, yielding five clusters ranging from twelve to 52 businesses per cluster. Mean scores for these items in each cluster appear in Table 2.

Table 2: Strategy Item Means for each Cluster

\begin{tabular}{lccccc}
\hline \multirow{2}{*}{ Variable } & \multicolumn{5}{c}{ Cluster Analysis } \\
& $\begin{array}{l}\text { Prospector } \\
(\mathbf{N = 3 1 )}\end{array}$ & $\begin{array}{c}\text { Reactor } \\
(\mathbf{N = 2 0})\end{array}$ & $\begin{array}{c}\text { Defender } \\
(\mathbf{N}=25)\end{array}$ & $\begin{array}{c}\text { Balancer } \\
(\mathbf{N}=\mathbf{2 8})\end{array}$ & $\begin{array}{c}\text { Analyzer } \\
(\mathbf{N}=\mathbf{2 9})\end{array}$ \\
\hline NEWPROD & 4.61 & 1.70 & 1.60 & 4.79 & 3.04 \\
STABPR & 4.48 & 1.60 & 4.60 & 4.00 & 2.89 \\
NPDEVEL & 4.68 & 1.50 & 1.52 & 4.66 & 3.21 \\
STPROF & 1.84 & 4.75 & 3.28 & 4.28 & 3.00 \\
MSHARE & 4.71 & 1.35 & 2.96 & 4.69 & 3.11 \\
RANGE & 4.65 & 1.10 & 3.16 & 4.14 & 3.11 \\
INNOVAT & 4.84 & 1.45 & 1.48 & 4.52 & 2.86 \\
ATTGROW & 4.71 & 1.40 & 3.16 & 4.34 & 2.96 \\
APPCUST & 4.42 & 1.45 & 3.44 & 4.83 & 2.93 \\
STABCUS & 4.48 & 1.40 & 2.84 & 4.83 & 3.04 \\
STAGROW & 4.52 & 1.15 & 2.96 & 4.72 & 3.25 \\
SPECIAL & 1.84 & 4.35 & 3.00 & 3.83 & 2.89 \\
FLEXIBL & 4.68 & 2.10 & 2.96 & 3.86 & 3.11 \\
MKTGSTR & 4.65 & 1.40 & 1.92 & 4.55 & 3.75 \\
LOWCOST & 1.42 & 4.70 & 2.48 & 1.97 & 3.00 \\
\hline
\end{tabular}

Businesses in the first cluster appear to be prospectors $(n=31)$, tending to score high on prospector items (e.g., emphasis new product leadership, development, market share, and growth; development of the customer base, and flexibility) while scoring low on defender items (e.g., stable profits, specialization, low cost emphasis). In contrast, businesses in the second cluster appear to be defenders $(n=25)$, tending to score low on prospector items and high on defender items.

Businesses in the third cluster appear to be reactors $(n=20)$, tending to score low on both prospector and defender items. In contrast, those in the fourth cluster appear to 
comprise the balancer cluster specifically sought in this study $(n=28)$, tending to score high on both sets of items. The final cluster demonstrates no clear high or low response tendencies and appears to be comprised of analyzers $(n=29)$. Businesses in the prospector, analyzer, defender, and balancer clusters-a total of 109 businesses-were retained for further analysis.

\section{Findings}

Table 3 provides revenue growth, ROA, and composite performance means for each of the strategy-background combinations addressed in the first four propositions. Table 4 provides the results of t-tests pitting those top executives with superior background-strategy "fits" against other top executives. These tests utilized the composite (COM) performance measure.

Table 3: Business Performance by CEO Background and Generic Strategy

CEO

$$
\text { Generic Strategy }
$$

Background

\begin{tabular}{|c|c|c|c|c|c|}
\hline & Prospector & Analyzer & Defender & Balancer & All Strategies \\
\hline $\begin{array}{l}\text { Research } \\
\text { Engineering }\end{array}$ & $\begin{array}{c}\mathrm{COM}=34.2 \\
\mathrm{GRO}=16.77 \\
\mathrm{ROA}=6.44 \\
\mathrm{~N}=8\end{array}$ & $\begin{aligned} \mathrm{COM} & =-75.7 \\
\mathrm{GRO} & =-1.58 \\
\mathrm{ROA} & =7.20 \\
\mathrm{~N} & =1\end{aligned}$ & $N=0$ & $\begin{aligned} \mathrm{COM} & =-40.9 \\
\mathrm{GRO} & =3.90 \\
\mathrm{ROA} & =7.53 \\
\mathrm{~N} & =3\end{aligned}$ & $\begin{array}{c}\mathrm{COM}=6.3 \\
\mathrm{GRO}=12.02 \\
\mathrm{ROA}=6.78 \\
\mathrm{~N}=12\end{array}$ \\
\hline $\begin{array}{l}\text { Marketing } \\
\text { Sales }\end{array}$ & $\begin{aligned} \mathrm{COM} & =-16.2 \\
\mathrm{GRO} & =8.09 \\
\mathrm{ROA} & =7.51 \\
\mathrm{~N} & =12\end{aligned}$ & $\begin{aligned} \mathrm{COM} & =25.49 \\
\mathrm{GRO} & =8.79 \\
\mathrm{ROA} & =8.08 \\
\mathrm{~N} & =15\end{aligned}$ & $\begin{aligned} \mathrm{COM} & =-65.2 \\
\mathrm{GRO} & =4.30 \\
\mathrm{ROA} & =5.40 \\
\mathrm{~N} & =7\end{aligned}$ & $\begin{aligned} \mathrm{COM} & =-26.8 \\
\mathrm{GRO} & =7.32 \\
\mathrm{ROA} & =6.72 \\
\mathrm{~N} & =10\end{aligned}$ & $\begin{aligned} \mathrm{COM} & =-12.8 \\
\mathrm{GRO} & =7.55 \\
\mathrm{ROA} & =7.19 \\
\mathrm{~N} & =44\end{aligned}$ \\
\hline $\begin{array}{l}\text { Accounting } \\
\text { Finance } \\
\text { Manuf. } \\
\text { Production }\end{array}$ & $\begin{aligned} \mathrm{COM} & =-80.1 \\
\mathrm{GRO} & =1.47 \\
\mathrm{ROA} & =3.03 \\
\mathrm{~N} & =6\end{aligned}$ & $\begin{aligned} \mathrm{COM} & =-8.4 \\
\mathrm{GRO} & =7.05 \\
\mathrm{ROA} & =8.15 \\
\mathrm{~N} & =4\end{aligned}$ & $\begin{aligned} \mathrm{COM} & =31.8 \\
\mathrm{GRO} & =3.50 \\
\mathrm{ROA} & =8.78 \\
\mathrm{~N} & =9\end{aligned}$ & $\begin{aligned} \mathrm{COM} & =-40.8 \\
\mathrm{GRO} & =3.94 \\
\mathrm{ROA} & =7.50 \\
\mathrm{~N} & =3\end{aligned}$ & $\begin{aligned} \mathrm{COM} & =-16.0 \\
\mathrm{GRO} & =3.65 \\
\mathrm{ROA} & =6.92 \\
\mathrm{~N} & =22\end{aligned}$ \\
\hline $\begin{array}{l}\text { General } \\
\text { Managemt. }\end{array}$ & $\begin{array}{c}\mathrm{COM}=60.4 \\
\mathrm{GRO}=19.88 \\
\mathrm{ROA}=8.05 \\
\mathrm{~N}=6\end{array}$ & $\begin{aligned} \mathrm{COM} & =-25.9 \\
\mathrm{GRO} & =5.08 \\
\mathrm{ROA} & =7.60 \\
\mathrm{~N} & =9\end{aligned}$ & $\begin{aligned} \mathrm{COM} & =55.8 \\
\mathrm{GRO} & =5.71 \\
\mathrm{ROA} & =8.45 \\
\mathrm{~N} & =4\end{aligned}$ & $\begin{array}{c}\mathrm{COM}=41.1 \\
\mathrm{GRO}=12.36 \\
\mathrm{ROA}=9.41 \\
\mathrm{~N}=12\end{array}$ & $\left\{\begin{array}{c}\mathrm{COM}=26.5 \\
\mathrm{GRO}=10.84 \\
\mathrm{ROA}=8.50 \\
\mathrm{~N}=31\end{array}\right.$ \\
\hline $\begin{array}{l}\text { All } \\
\text { Backgrounds }\end{array}$ & $\begin{array}{c}\mathrm{COM}=-1.2 \\
\mathrm{GRO}=11.23 \\
\mathrm{ROA}=6.50 \\
\mathrm{~N}=32\end{array}$ & $\begin{aligned} \mathrm{COM} & =-0.3 \\
\mathrm{GRO} & =7.04 \\
\mathrm{ROA} & =7.91 \\
\mathrm{~N} & =29\end{aligned}$ & $\begin{aligned} \mathrm{COM} & =2.6 \\
\mathrm{GRO} & =4.22 \\
\mathrm{ROA} & =7.53 \\
\mathrm{~N} & =20\end{aligned}$ & $\begin{aligned} \mathrm{COM} & =-1.4 \\
\mathrm{GRO} & =8.75 \\
\mathrm{ROA} & =8.04 \\
\mathrm{~N} & =28\end{aligned}$ & $\begin{aligned} \mathrm{COM} & =0 \\
\mathrm{GRO} & =8.19 \\
\mathrm{ROA} & =7.46 \\
\mathrm{~N} & =109\end{aligned}$ \\
\hline
\end{tabular}


Table 4: Hypothesized CEO Background-Generic Strategy Relationships.

\begin{tabular}{|c|c|c|c|c|c|c|}
\hline $\begin{array}{l}\text { Generic } \\
\text { Strategy }\end{array}$ & $\begin{array}{l}\text { Best Fit } \\
\text { CEO's }\end{array}$ & $\begin{array}{l}\text { Performance } \\
\text { (COM) }\end{array}$ & $\begin{array}{l}\text { Other } \\
\text { CEO's }\end{array}$ & $\begin{array}{l}\text { Performance } \\
\text { (COM) }\end{array}$ & $\mathrm{t}$-value & signif. \\
\hline Prospector & $\begin{array}{l}\text { Research } \\
\text { Engineering } \\
\text { Gen Mgmt }\end{array}$ & 47.44 & $\begin{array}{l}\text { Marketing } \\
\text { Acc/Finance } \\
\text { Production }\end{array}$ & -39.51 & 2.51 & .018 \\
\hline Analyzer & Marketing & 25.49 & $\begin{array}{l}\text { Research } \\
\text { Engineering } \\
\text { Gen Mgmt } \\
\text { Acc/Finance } \\
\text { Production }\end{array}$ & -26.48 & 2.66 & .013 \\
\hline Defender & $\begin{array}{l}\text { Acc/Finance } \\
\text { Production } \\
\text { Gen Mgmt }\end{array}$ & 39.16 & $\begin{array}{l}\text { Research } \\
\text { Engineering } \\
\text { Marketing }\end{array}$ & -65.20 & 2.15 & .045 \\
\hline Balancer & Gen Mgmt & 41.14 & $\begin{array}{l}\text { Research } \\
\text { Engineering } \\
\text { Marketing } \\
\text { Acc/Finance } \\
\text { Production }\end{array}$ & -33.77 & 3.33 & .003 \\
\hline
\end{tabular}

The first proposition was supported. Only top executives from the two hypothesized backgrounds-research/engineering and general management-tended to perform above the sample median $(\mathrm{COM}=47.44)$ when the prospector strategy was adopted. Prospectors managed by top executives with marketing/sales, accounting/finance, and manufacturing/ production backgrounds were much less adept formulating and implementing the strategy (COM=-39.51). The $t$-value of 2.51 suggested that these performance differences were significant at the .05 level.

The second proposition was supported. Considering analyzers, the only group of executives to average above the median was the marketing/sales group (COM=25.49). All other groups performed below the median, with a mean composite measure of -26.48 . The t-value of 2.66 suggested that these performance differences were significant at the .05 level.

The third proposition was supported. Considering defenders, top executives with general management backgrounds ( $\mathrm{COM=55.8)}$ and accounting/finance or manufacturing/production backgrounds $(\mathrm{COM}=31.8)$ outperformed those with marketing backgrounds $(\mathrm{COM}=-65.2)$. This difference was significant at the .05 level (t-value $=2.15$ ).

The fourth proposition was supported. Considering balancers, the only executive group to average above the performance median was the generalist group (COM=41.14). All 
other groups of top executives performed well below the median, with an average composite measure of -33.77 . This difference was significant at the .05 level ( $t$-value=3.33).

The fifth proposition was not supported. In fact, none of the three experience variablesexperience in the organization, experience as top executive, and experience in the industry-was significantly correlated with revenue growth, ROA, or the composite performance measure.

\section{Discussion and Prospects For Future Research}

The significance of this initial study centers around three key points. First, the successful formulation and implementation of strategies at the business level is related to the skills and perspective of the top executive. Specifically, top executives with expertise in the distinctive competencies highlighted by the prospector, analyzer, defender, or balancer strategy chosen tend to achieve greater performance for their organizations. This finding suggests that regardless of the increased influence by boards of directors and top management teams, the background of the top executive remains a major factor in the formula for high performance and should be a major consideration in appointment decisions.

This study did not address how the top executive-strategy relationship emerged in the businesses. For example, did the top executives tend to mold the strategies around their own biases and specialties, or were the top executives originally selected to modify and implement a strategy already in action (Litchfield 1990)? Does top management team homogeneity or heterogeneity moderate or mediate the background-strategy-performance relationship (Murray 1989)?

This study also did not demonstrate the existence of a universal executive-strategy contingency. Future research should also consider manufacturing industries. Many of the skills and behaviors required for successful strategic implementation may be industryspecific as well as strategy-specific. Hence, it is possible that a three-way interaction (i.e., strategy, functional background, and industry type) may be found.

Second, top executive characteristics not directly associated with their skills and competencies were not significantly associated with business performance. Contrary to conventional wisdom, experience at the helm, with the company, and in the industry were not relevant. Since it is generally accepted that many skills can be nurtured and strengthened over time, future research should consider the possible disadvantages associated with experience. These may center around the narrowing of perspectives over time, as top managers attempt to maintain their competitive advantage by recreating successful strategies in the past-strategies that may never again result in superior performance (Parnell, Lado, and Wright 1992)!

Finally, this study did not address the superiority of any given background. Although executives with general management backgrounds were most successful in this study, this did not hold true for all four viable strategies. Indeed, numerous writers have suggested that the most appropriate top executive background is contingent on industrial and economic trends (Boone and Milewicz 1989; Braham 1991; Kichen and Hardy 1992; 
Litchfield 1990). From this perspective, it is possible that optimal strategies can be identified for certain industries and time periods. Tenets such as flexibility (Stewart 1992), speed-to-market (Stalk 1988), and quality (Drucker 1990) may be characteristics of effective strategies in the 1990s, but they may be irrelevant to effective strategies in the next decade. Hence, future research should consider how changes among industries and in the environment over time impact the effectiveness of a variety of strategy-related factors, including the background of the top executive.

\section{References}

Andrews, K.R. 1971. The Concept of Corporate Strategy. Homewood, IL: Dow-Jones Irwin.

Barney, J.B. and R.E. Hoskisson. 1990. "Strategic Groups: Untested Assertions and Research Proposals." Managerial and Decision Economics 11: 187-198.

Boone, L.E., and D.L. Kurtz. 1988. "CEOs: A Group Profile." Business Horizons 31(4): 38-42.

Boone, L.E., and J.C. Milewicz. 1989. "Is Professional Selling the Route to the Top of the Corporate Hierarchy?" Journal of Personal Selling and Sales Management 9(1): 42-54.

Braham, J. 1991. "Engineering Your Way to the Top." Machine Design 63(7): 65-68.

Buzzell, R.D., and B.T. Gale. 1987. The PIMS Principles. New York: Free Press.

Cappel, S.D. 1990. "Strategic Profiles and Performance in Service Organizations: Examining Retail Department, Variety and General Merchandise Stores." Unpublished doctoral dissertation, Memphis State University, Memphis, Tennessee.

Cronbach, L.J. 1951. "Coefficient Alpha and the Internal Structure of Tests." Psychometrica 16: 297-334.

Dess, G.G., and P.S. Davis. 1984. "Porter's Generic Strategies as Determinants of Strategic Group Membership and Performance." Academy of Management Journal 26: 467-488.

Dommermuth, W.P. 1966. "On the Odds of becoming Company President." Harvard Business Review 44(3): 65-72.

Drucker, P.F. 1990. "The Emerging Theory of Manufacturing." Harvard Business Review 68(3): 94-102.

Eisman, R. 1992. "Why Companies are Turning to Total Quality." Incentive 166(5): 22-26.

Flannigan, W.G. 1986. "How Much the Bosses Earned." Forbes 143(12): 150-188.

Futrell, C. 1988. Sales Management. Hinsdale, IL: Dryden Press. 
Govindarajan, V. 1989. "Implementing Competitive Strategies at the Business Unit Level: Implications of Matching Managers to Strategies." Strategic Management Journal 10: 251-269.

Gupta, A.K., and V. Govindarajan. 1984. "Business Unit Strategies, Managerial Characteristics, and Business Unit Effectiveness at Strategy Implementation." Academy of Management Journal 27: 25-41.

Hambrick, D.C. 1983. "Some Tests of the Effectiveness and Functional Attributes of Miles and Snow's Strategic Types." Academy of Management Journal 26: 5- 26.

Hambrick, D.C., and P.A. Mason. 1984. "Upper Echelons: The Organization as a Reflection of Its Top Managers." Academy of Management Review 9: 193-206.

Hendricks, C.F., and A. Triplett. 1989. "TQM: Strategy for '90's Management." Personnel Administration 34(12): 42-47.

Herbert, T.T., and H. Deresky. 1987. "Generic Strategies: An Empirical Investigation of Typology Validity and Strategy Content." Strategic Management Journal 8: 135-147.

Hill, C.W.L. 1988. "Differentiation Versus Low Cost or Differentiation and Low Cost: A Contingency Framework." Academy of Management Review 13: 401-412.

Hise, R.T., and S.W. McDaniel. 1988. "American Competitiveness and the CEO-Who's Minding the Shop?" Sloan Management Review 29(2): 49-55.

Jones, G.R., and J.E. Butler. 1988. "Costs, Revenue, and Business-level Strategy." Academy of Management Review 13(2): 202-213.

Kichen, S., and E.S. Hardy. 1992. "Putting It into Perspective." Forbes 149(11): 174-176.

Kotter, J.P. 1982. The General Managers. New York: Free Press.

Kurtz, D.L., L.E. Boone, and C.P. Fleenor. 1989. CEO: Who Gets to the Top in America. East Lansing, MI: Michigan State University Press.

Kurtz, H., R. Dodge, and J.E. Klompmaker. 1988. Professional Selling. Plano, TX: Business Publications, Inc.

Lawless, M.W., and L.K. Finch. 1989. "Choice and Determinism: A Test of Hrebiniak and Joyce's Framework on Strategy-Environment Fit." Strategic Management Journal 10: 351-365.

Leontiades, M. 1982. "Choosing the Right Manager to Fit Strategy." Journal of Business Strategy 3: $58-69$.

Litchfield, R. 1990. "They Walk on Water." Canadian Business 63(9): 46-49.

Miles, R.E., and K. Cameron. 1982. Coffin Nails and Corporate Strategies. Englewood Cliffs, NJ: Prentice-Hall. 
Miles, R.E., and C.C. Snow. 1978. Organizational Strategy. Structure, and Process. New York: West.

Miles, R.E., and C.C. Snow. 1986. "Organizations: New Concepts for New Forms." California Management Review 18(3): 62-73.

Miller, D., and P.H. Friesen. 1986. "Porter's (1980) Generic Strategies and Performance: An Empirical Examination with American Data. Part II: Performance Implications." Organization Studies 7: 255-261.

Miller, D., M.F.R. Kets de Vries, and J.M. Toulouse. 1982. "Top Executive Locus of Control and Its Relationship to Strategy-making, Structure, and Environment." Academy of Management Journal 25: 237-253.

Murray, A.I. 1988. "A Contingency View of Porter's 'Generic Strategies." Academy of Management Review 13: 390-400.

Murray, A.I. 1989. “Top Management Group Heterogeneity and Firm Performance.” Strategic Management Journal 10 (Summer, Special Issue): 125-141.

Namiki, N. 1989. "Miles and Snow's Typology of Strategy, Perceived Environmental Uncertainty, and Organizational Performance." Akron Business and Economic Review 20(2): 72-88.

Norburn, D. 1989. “The Chief Executive: A Breed Apart.” Strategic Management Journal 10(1): 1-15.

Norburn, D., and S. Birley. 1988. "The Top Management Team and Corporate Performance." Strategic Management Journal 9: 225-238.

Parnell, J.A., A. Lado, and P. Wright. 1992. "Why Good Things Never Seem to Last: A Dialectic Perspective on Long-term Competitive Advantage." Journal of Business Strategies 9 (1): $62-$ 68.

Parnell, J.A., and P. Wright. 1992. "Generic Strategy and Performance: An Empirical Test of the Miles and Snow Typology." British Journal of Management, in press.

Peter, J.P. 1979. "Reliability: A Review of Psychometric Basics and Recent Marketing Practices." Journal of Marketing Research 16: 6-17.

Porter, M.E. 1985. Competitive Advantage. New York: Free Press.

Porter, M.E. 1980. Competitive Strategy. New York: Free Press.

Sashkin, M., and Kiser, K. 1992. "What is TQM?" Executive Excellence 5 (5): 11.

Snow, C.C., and L.G. Hrebiniak. 1980. "Strategy, Distinctive Competence, and Organizational Performance." Administrative Science Quarterly 25: 317-336. 
Stalk, G., Jr. 1988. "Time-The Next Source of Competitive Advantage." Harvard Business Review 66(4): $41-51$.

Stewart, T.A. 1992. "Brace for Japan's Hot New Strategy." Fortune 126(6): 62-74.

Thomas, A.S., R.J. Litschert, and K. Ramaswamy. 1991. "The Performance Impact of StrategyManager Coalignment: An Empirical Examination." Strategic Management Journal 12: 509-522.

Thomas, H., and N. Venkatraman. 1988. "Research on Strategic Groups: Progress and Proposals." Journal of Management Studies 25: 537-555.

Virnay, B., and M.L. Tushman. 1986. "Executive Succession: The Changing Characteristics of Top Management Teams." Academy of Management Best Paper Proceedings, pp. 155-159.

Ward's Business Directory 1992. Ward's Directory of U.S. Private and Public Companies. New York: Gale Research.

White, R.E. 1986. "Generic Business Strategies, Organizational Context, and Performance: An Empirical Investigation." Strategic Management Journal 7: 217-231.

Wright, P. 1987. “A Refinement of Porter's Strategies." Strategic Management Journal 8: 93101.

Wright, P., M. Kroll, C. Pringle, and J. Johnson. 1990. "Organization Types, Conduct, Profitability and Risk in the Semiconductor Industry." Journal of Management Systems 2(2): 33-48.

Wright, P., and A. Parsinia. 1988. "Porter's Synthesis of Generic Business Strategies: A Critique." Industrial Management 1: 20-23. 